Natalia Maria Tończyk

Uniwersytet Mikołaja Kopernika, Toruń

\title{
Konstytucja Republiki Weimarskiej z 11 sierpnia 1919 roku jako demokratyczna podstawa prawna totalitarnego państwa
}

DOI: http://dx.doi.org/10.12775/SIT.2014.018

\section{Kontekst historyczny. Geneza konstytucji weimarskiej}

Po zakończeniu działań wojennych w listopadzie 1918 roku. Niemcy stanęły przed pilną koniecznością uporządkowania sytuacji wewnętrznej państwa. Klęska poniesiona w wojnie, zniszczenia kraju i pogarszająca się kondycja społeczno-gospodarcza doprowadziły do ogólnego niezadowolenia społecznego, skutkiem czego była m.in. niestabilna sytuacja polityczna przejawiająca się choćby w radykalizacji poglądów i nastrojów, a następnie wystąpieniach rewolucyjnych. $Z$ wszystkimi tymi problemami państwo niemieckie musiało się jak najszybciej zmierzyć. Wobec narastającego napięcia i groźby ogarnięcia zamieszkami całego kraju oraz rewolucji w Berlinie, 9 listopada 1918 roku cesarz Wilhelm II został zmuszony do abdykacji ${ }^{1}$ (formalna abdykacja cesarza i następcy tronu odbyła się

${ }^{1}$ Zob. W. Czapliński, A. Galos, A. Korta, Historia Niemiec, Wrocław 2010, s. 576. 
28 listopada i 1 grudnia 1918 roku$^{2}$ ). Tego samego dnia Philipp Scheidemann, bez konsultacji z Friedrichem Ebertem i przy jego ostrej krytyce, proklamował powstanie republiki, kończąc tym samym epokę monarchii w Niemczech ${ }^{3}$. Władzę w państwie przejęła, utworzona przez Eberta 10 listopada 1918 roku i złożona $\mathrm{z}$ socjalistów z SPD i USPD, Rada Pełnomocników Ludowych (Rat der Volksbeauftragten), będąca prowizorycznym rządem. Jej zadaniami było wyciszenie rewolucji, zaprowadzenie względnego porządku w kraju i doprowadzenie do wyborów, w wyniku których wyłonione miały zostać nowe władze centralne Republiki Niemieckiej. $\mathrm{W}$ celu realizacji tego ostatniego punktu przyjęta została ustawa o wyborze władz Rzeszy z 30 listopada 1918 roku. Wybory do Zgromadzenia Narodowego, zarządzone przez Eberta, odbyły się 19 stycznia 1919 roku. Niewątpliwie były one ważnym krokiem na drodze do nowego bezpiecznego konstytucyjnoprawnego porządku Ze względu na napięcie społeczne, a także w celu oddzielenia się od prusko-cesarskiej tradycji obrady nowo wybranego Zgromadzenia Narodowego (6 lutego 1919 roku) rozpoczęły się nie w Berlinie, ale w Weimarze $\mathrm{e}^{5}$ - stąd potoczna nazwa nowego państwa niemieckiego i nowej konstytucji. W ciągu niecałego tygodnia od rozpoczęcia obrad Zgromadzenie uchwaliło tzw. małą konstytucję regulującą podstawowe kwestie dotyczące ustroju - państwo niemieckie miało być republiką, powołano prezydenta (którym został Friedrich Ebert) i rząd (był to pierwszy niemiecki demokratycznie wybrany rząd koalicyjny, a w jego skład weszli socjaliści, demokraci i przedstawiciele Centrum). Działania te urzeczywistniały założenie, zgodnie z którym Republika Niemiecka miała być oparta na zasadach demokracji parlamentarnej według zachodniego wzorca. Podkreślić jednak należy, że obrady w Weimarze nie uspokoiły sytuacji wewnętrznej państwa, które w obliczu ciągłych niepokojów funkcjonowało do czasu uchwalenia konstytucji na podstawie ustawy o tymczasowej władzy Rzeszy z 10 lutego 1919 roku.

${ }^{2}$ D. Willoweit, Deutsche Verfassungsgeschichte. Vom Frankenreich bis zur Wiedervereinigung Deutschlands, München 2013, s. 457.

${ }^{3}$ W. Frotscher, B. Pieroth, Verfassungsgeschichte, München 2013, s. 249.

${ }^{4}$ Ibidem, s. 252.

${ }^{5}$ W. Czapliński, A. Galos, A. Korta, op.cit., s. 579. 


\section{Uchwalenie konstytucji}

Mimo podjęcia najbardziej pilnych decyzji, praca Zgromadzenia Narodowego nie była skończona. Najważniejszym bowiem jego zadaniem było uchwalenie nowej konstytucji, która byłaby formalnoprawną podstawą funkcjonowania Republiki ${ }^{6}$. Głównym jej twórcą był demokrata i liberał, prawnik, profesor Hugo Preuß. Przygotował on dwa projekty: pierwszy, jeszcze ze stycznia 1919 roku, został odrzucony. Dlatego od 24 lutego 1919 roku (przy współpracy 28-osobowej Komisji Konstytucyjnej) rozpoczęły się prace nad drugim projektem. Przez kolejne miesiące Zgromadzenie Narodowe pracowało nad pojedynczymi artykułami konstytucji weimarskiej, a ożywione spory oddziaływały na podejmowane decyzje ${ }^{7}$. Po trzecim czytaniu, projekt konstytucji 31 lipca 1919 roku został przyjęty większością głosów (282 - za, 75 - przeciw, 1 osoba wstrzymała się od głosu). Prezydent Ebert 11 sierpnia 1919 roku podpisał akt konstytucyjny i ogłosił go.

\section{Materia konstytucyjna}

Konstytucja weimarska (Die Verfassung des Deutschen Reichs vom 11. August 1919) była wzorowana na poprzednich konstytucjach niemieckich - konstytucji niemieckiej z 1849 roku i Konstytucji II Rzeszy z 1871 roku. Wybitny niemiecki prawnik Gerhard Anschütz, pisząc w Komentarzu o regulacjach konstytucji weimarskiej, stwierdził nawet, że choć „konstytucja się zmieniła, to państwo

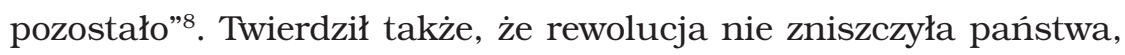

${ }^{6}$ K. Kamińska, A. Gaca, Historia powszechna ustrojów państwowych, Toruń 2011 , s. 618.

${ }^{7}$ G. Lingelbach, Weimar 1919 - Weg in eine Demokratie, w: 80 Jahre Weimarer Reichsverfassung - Was ist geblieben?, red. E. Eichenhofer, Tübingen 1999, s. 41.

${ }^{8}$ G. Anschütz, Die Verfassung des Deutschen Reichs vom 11. August 1919, Berlin 1933, cyt. za: W. Frotscher, B. Pieroth, op.cit., s. 257, tłum. autorki. 
lecz tylko zmieniła jego konstytucję . Można jednak uznać, że jest to teza zbyt daleko idąca. Konstytucja weimarska wywodziła się bowiem z tradycji konstytucji z 1871 roku, ale nie była jej wierną kopią, a zasady regulujące funkcjonowanie państwa, przynajmniej w teorii, znacznie odbiegały od tych z 1871 roku, a co za tym idzie powinny były tworzyć inny byt państwowy. Poza tym, jak już było wspomniane, część założeń konstytucji z 1919 roku pochodziła z konstytucji z 1849 roku, co podkreślają Werner Frotscher i Bodo Pieroth $^{10}$. Normy wcześniejszych konstytucji niemieckich, których ślady możemy odnaleźć w weimarskiej ustawie zasadniczej, zostały odpowiednio zmienione i dopasowane do ówczesnej rzeczywistości (koniecznie trzeba tu podkreślić fakt, że wpływ na uchwalenie tego aktu prawnego i jego treść miały środowiska centrowe, a nie skrajnie prawicowe lub lewicowe, co klarownie tłumaczy jego kształt). Można postawić tezę, że była to konstytucja prawie idealna. Wprowadzała nowoczesne, jak na tamte czasy, demokratyczne standardy będące wówczas całkowitym novum. Jej rozwiązania tak dalece wyprzedzały czas, w którym powstały, że większość jej przepisów mogłaby znaleźć się w współczesnych konstytucjach.

Całość konstytucji składała się z: krótkiej preambuły, części I: „Organizacja i zadania Rzeszy”, części II: „Podstawowe prawa i obowiązki Niemców” oraz przepisów przejściowych i końcowych.

\subsection{Organizacja i zadania Rzeszy}

Część I konstytucji, zgodnie z jej tytułem, zawierała regulacje dotyczące organizacji i zadań Rzeszy. Artykuł 1 stanowił: „Rzesza Niemiecka jest republiką. Władza państwowa pochodzi od narodu"11. Pierwsze zdanie definitywnie określa ustrój, formalnie uniemożliwiając wprowadzenie jakiejkolwiek innej formy rządów - monarchii, oligarchii czy dyktatury ludu ${ }^{12}$. Tym samym ostatecznie usunięto

9 Ibidem.

${ }^{10}$ W. Frotscher, B. Pieroth, op.cit., s. 258.

${ }_{11}$ Die Verfassung der Weimarer Republik vom 11. August 1919, Stuttgart 2009, s. 3, tłum. autorki.

12 G. Anschütz, Die Verfassung des Deutschen Reichs vom 11. August 1919, Berlin 1926, s. 37. 
monarchię $\mathrm{z}$ niemieckiego porządku konstytucyjnego oraz ustanowiono suwerenność ludu, tworząc podstawy demokracji ${ }^{13}$. Za suwerena uznano tutaj cały naród, a nie tylko wybrane grupy społeczne czy też przedstawicieli poszczególnych krajów związkowych. Lud wykonywał swoją władzę poprzez udział w wyborach, a także referendach i plebiscytach.

Konstytucja nadała państwu niemieckiemu charakter federacji. Ta związkowa republika liczyła początkowo 21, a potem 18 krajów związkowych. Landy miały mieć własne - odrębne sejmy, rządy i konstytucje, a także prawo do własnej polityki wewnętrznej. W art. 5 założono rozdzielność władzy państwowej w Rzeszy i w krajach związkowych poprzez oddzielne organy i konstytucje, tzn. władza w zakresie spraw Rzeszy miała być wykonywana przez organy Rzeszy na podstawie jej konstytucji, a w zakresie spraw krajów związkowych przez organy krajowe na podstawie konstytucji krajowych ${ }^{14}$. Akt konstytucyjny szczegółowo regulował także kompetencje ustawodawcze Rzeszy i landów, zachowując rozdział między nimi. Artykuł $6 \mathrm{w}$ siedmiu punktach zawierał wyłączne, bezwzględne kompetencje Rzeszy, do których zaliczono: politykę zagraniczną, sprawy kolonii, kwestie obywatelstwa, wolności przesiedlania się, emigracji, imigracji i deportacji, sprawy sił zbrojnych, kwestie monetarne, ceł i wolności celnych oraz wolności handlowych, a także sprawy łączności. Artykuł 7 omawiał pozostałe uprawnienia Rzeszy, a art. 10 nadawał Rzeszy jeszcze względne prawo ustawodawcze. Rzesza, choć miała charakter związkowy, została wyposażona w silne elementy centralistyczne. Obowiązywał prymat prawa Rzeszy - kraje związkowe zachowywały kompetencje ustawodawcze tylko tak długo, jak długo Rzesza nie czyniła użytku ze swojego prawodawstwa (zob. art. 12) ${ }^{15}$. Ponadto Rząd Rzeszy miał wykonywać nadzór nad sprawami, co do których Rzesza ma uprawnienia ustawodawcze (art. 15). Ustawy Rzeszy miały także być wprowadzane i wykonywane przez władze krajów związkowych (art. 14). Mimo, że landy zachowywały pewną

${ }^{13}$ W. Frotscher, B. Pieroth, op.cit., s. 258.

${ }_{14}$ Die Verfassung der Weimarer Republik vom 11. August 1919, Stuttgart 2009, s. 4.

15 Ibidem, s. 7. 
dozę niezależności, to np. zmiany terytorialne dotyczące zmian ich granic mogły być przeprowadzone przez Rzeszę nie tylko za zgodą zainteresowanych krajów, ale również przy ich sprzeciwie, przy poparciu ludności wyrażonym w głosowaniu (art. 18).

Konstytucja weimarska wprowadziła zasadę trójpodziału władz. Centralnym organem Rzeszy został Sejm Rzeszy (Reichstag), co jest znakiem przyjęcia formy rządów parlamentarnych. Do niego należała pełnia władzy ustawodawczej. Składał się z posłów, będących obywatelami niemieckimi (art. 20) i przedstawicielami całego narodu, którzy podlegają tylko sumieniu i nie są związani instrukcjami (art. 21) ${ }^{16}$. Posłowie byli zatem wolni w sprawowaniu swojego mandatu. Konstytucja przewidywała także bardzo demokratyczną regulację dotyczącą wyborów do Sejmu Rzeszy - były one powszechne, równe, bezpośrednie i tajne. Prawo wyborcze posiadali wszyscy obywatele, którzy ukończyli 20 lat, zarówno mężczyźni, jak i kobiety. Dzień wyborów ustalony był na niedzielę albo inny dzień wolny od pracy (art. 22). Kadencja Sejmu trwała 4 lata (art. 23). Posłowie posiadali immunitet materialny i formalny (art. 36 i 37). Obrady Sejmu były jawne (art. 29), choć w wyjątkowych przypadkach jawność mogła być wykluczona, a uchwały co do zasady były podejmowane zwykłą większością głosów, chyba że konstytucja stanowiła inaczej (art. 32). Do kompetencji Sejmu oprócz uprawnień ustawodawczych, takich jak inicjatywa ustawodawcza i wyłączne prawo uchwalania ustaw ${ }^{17}$ (art. 68) oraz możliwość zmiany konstytucji, należy zaliczyć kontrolowanie Rządu Rzeszy i nadawanie mu ogólnego kierunku polityki ${ }^{18}$.

Rząd Rzeszy (Reichsregierung) składał się z Kanclerza Rzeszy (Reichskanzler) i Ministrów Rzeszy (Reichsministern) (art. 52). Kanclerz i na jego wniosek ministrowie byli mianowani i powoływani przez Prezydenta (art. 53). Kanclerz przewodniczył Rządowi i prowadził jego prace (art. 55) oraz ustalał wytyczne polityki Rządu, za które był

16 Ibidem, s. 11.

17 Choć w kwestii ogłaszania, wchodzenia w życie i odraczania ustaw konstytucja nie była tak jednolita - dawała możliwość odwołania się do referendum ludowego albo do Prezydenta Rzeszy.

18 K. Kamińska, A. Gaca, op.cit., s. 620. 
odpowiedzialny przed parlamentem (art. 56). Ministrowie w zakresie wymienionych wytycznych kierowali samodzielnie powierzonymi im resortami, ponosząc za to odpowiedzialność przed Sejmem (art. 56). Rząd miał także prawo inicjatywy ustawodawczej (art. 68). Kanclerz, a także ministrowie za zawinione naruszenie konstytucji lub ustawy Rzeszy ponosili odpowiedzialność konstytucyjną przed Najwyższym Trybunałem Rzeszy (art. 59). Ważną nowością przewidzianą przez konstytucję była zależność Rządu od większości parlamentarnej ${ }^{19}$, tzn. wprowadzenie instytucji wotum zaufania i wotum nieufności $\mathrm{w}$ art. 54, zgodnie $\mathrm{z}$ którym Kanclerz i ministrowie mogą objąć swój urząd tylko wtedy, gdy zostało im udzielone wotum zaufania, a w przypadku cofnięcia go - muszą ustąpić.

Prezydent Rzeszy (Reichspräsident) posiadał silny mandat obywatelski, był bowiem wybierany przez naród w głosowaniu powszechnym (art. 41). Kadencja trwała siedem lat i dopuszczalny był ponowny wybór. Złożenie Prezydenta $z$ urzędu było możliwe na wniosek Sejmu w głosowaniu ludowym (art. 43). Do konstytucyjnych kompetencji Prezydenta zaliczyć należy: reprezentowanie państwa na arenie międzynarodowej i prowadzenie polityki zagranicznej, wypowiadanie wojny i zawieranie pokoju (art. 45), a także powoływanie Kanclerza i na jego wniosek ministrów (art. 53) oraz mianowanie urzędników Rzeszy (art. 46). Ponadto był zwierzchnikiem sił zbrojnych (art. 47). Posiadał także prawo łaski (art. 49). Do jego obowiązków należało również zarządzenie referendum w sytuacjach określonych w konstytucji. Miał również prawo rozwiązania Sejmu Rzeszy, ale tylko jeden raz z tego samego powodu (art. 25). Bardzo ważna kompetencja Prezydenta wyrażona była w art. 48 konstytucji. Na podstawie tego przepisu, w przypadku, w którym kraj związkowy nie spełniał obowiązków nałożonych na niego przez konstytucję lub ustawę Rzeszy, Prezydent miał prawo zmusić kraj ten do wykonania ich przy pomocy sił zbrojnych. Artykuł 48 dawał mu także uprawnienia do podobnej interwencji w sytuacji zagrożenia bezpieczeństwa i porządku publicznego oraz częściowego lub całkowitego zawieszenia niektórych praw i wolności.

${ }^{19}$ W. Frotscher, B. Pieroth, op.cit., s. 262. 
Rada Rzeszy (Reichsrat) była organem federalnym reprezentującym poszczególne kraje związkowe. Każdy z landów miał w Radzie przynajmniej jeden głos, ale żaden $z$ nich nie mógł mieć więcej niż ${ }^{2} / 5$ wszystkich głosów (art. 61). Była to niewątpliwie kolejna regulacja zawarta w tej Konstytucji w celu zmniejszenia znaczenia większych landów (przede wszystkim Prus) i ich dominacji nad innymi krajami. W Radzie jako reprezentanci zasiadali członkowie rządów krajowych (art. 63). Do jej uprawnień należało m.in.: opiniowanie projektów ustaw Rządu w postaci wyrażenia zgody lub zdania odrębnego (art. 69) oraz weto zawieszające ustawy uchwalone przez Sejm (art. 74).

Republikę Weimarską można określić jako związkową republikę parlamentarną ze znacznym elementem plebiscytowym. Mimo że władze centralne posiadały silny mandat, to konstytucja wielokrotnie przewidywała także formy demokracji bezpośredniej. Pod referendum ludowe można było poddać np. ustawę uchwaloną przez Sejm (kiedy Prezydent podjął taką decyzję), projekt ustawy (art. 73), a także w sytuacji, gdy Rada Rzeszy złożyła sprzeciw wobec ustawy uchwalonej przez Sejm i spór ten nie został rozwiązany (art. 74). W drodze referendum ludowego dopuszczalna była również zmiana konstytucji (art. 76).

Konstytucja weimarska wprowadzała także szereg regulacji dotyczących wymiaru sprawiedliwości. Przyznawała sędziom mianowanym dożywotnio (art. 104) ustawową ochronę pełnienia zawodu. Wprowadzała zasadę niezawisłości sędziowskiej (art. 102). Wykonywanie władzy sądowniczej przyznano Sądowi Rzeszy i sądom krajowym (art. 103), sądy wojskowe miały kompetencje wyłącznie w czasie wojny i w sprawach popełnionych na okręcie wojennym (art. 106). Konstytucja przewidywała również plany ustanowienia sądów administracyjnych dla ochrony jednostek w stosunku do rozporządzeń i zarządzeń władzy administracyjnej (art. 107). Umocowała prawnie także istnienie Najwyższego Trybunału Rzeszy (art. 108), któremu przyznała szereg kompetencji ${ }^{20}$.

${ }^{20}$ Akt konstytucyjny odwoływał się do kompetencji i działania Najwyższego Trybunału Rzeszy, a także do jego „powiązań” z innymi organami władzy 


\subsection{Podstawowe prawa i obowiązki Niemców}

Konstytucja weimarska wprowadzała również szeroki katalog praw i wolności. Ich zakres zawarty był w części II konstytucji: „Podstawowe prawa i obowiązki Niemców” (art. 109-165). Już art. 109 wskazywał na pełną równość obywateli niemieckich wobec prawa. Znaczenia nie miało pochodzenie czy przynależność do danego stanu - zniesione zostały zarówno publicznoprawne przywileje, jak i ograniczenia, wypływające $z$ urodzenia. Ponadto artykuł ten ustanawiał równouprawnienie kobiet i mężczyzn ${ }^{21}$. Konstytucja gwarantowała wolność (art. 114) - była ona nienaruszalna, a jej ograniczenie mogło nastąpić tylko przez władzę publiczną na mocy ustawy. Wśród innych praw, które przysługiwały jednostce wymienić można: wolność osiedlania się i przemieszczania (art. 112 i 113), zakaz ekstradycji (art. 113), wolność słowa, myśli i druku (art. 118), nietykalność mieszkania (art. 115), tajemnicę korespondencji (art. 117). Konstytucja poddawała też ochronie obcojęzyczną część ludności Rzeszy (art. 113) oraz expressis verbis wyrażała zasadę nulla poena sine lege anteriori (art. 116).

Regulacji konstytucyjnoprawnej podlegały także prawa związane $z$ życiem społecznym. Były to zarówno prawa obywatelskie, takie jak: wolność zgromadzeń (art. 123), wolność zrzeszania się (art. 124), prawo do wolnych i tajnych wyborów (art. 125), jak i prawo do równego dostępu do stanowisk urzędniczych (art. 128). Akt konstytucyjny zawierał także prawa prorodzinne - małżeństwo oparte na równouprawnieniu płci i rodzina podlegały szczególnej ochronie państwa (art. 119). Poza tym zrównano status prawny dzieci nieślubnych ze statusem dzieci pochodzących z małżeństwa (art. 121).

państwowej w wielu miejscach - poza wspomnianym art. 109, np. w art. 19 albo 59.

${ }^{21}$ Wątpliwości budziło dodane w tym artykule słowo „zasadniczo”, co wskazywać mogło na pewne ograniczenia w stosowaniu zasady zrównania praw płci. Jednakże na podstawie tego artykułu zostało wyprowadzone bierne prawo wyborcze dla kobiet. Zob. W. Frotscher, B. Pieroth, op.cit., s. 267. 
Konstytucja gwarantowała także pełną wolność religijną. Owa wolność wyznania i sumienia przejawiała się nie tylko w postaci prawa do niezakłóconego kultu i praktyk religijnych (art. 135), ale też $\mathrm{w}$ prawie do zachowania $\mathrm{w}$ tajemnicy wyznawanej religii i braku obowiązku deklarowania jej władzy państwowej. Również korzystanie $z$ praw cywilnych i obywatelskich było niezależne od wyznawanej religii (art. 136). Zapewniona była też własność majątków związków i organizacji religijnych (art. 138). Wprowadzono także klauzulę, zgodnie $z$ którą nie było jednego, określonego kościoła państwowego (art. 137). Wypracowanie tych rozwiązań prawnych poprzedziły w czasie układania tekstu konstytucji długie dyskusje między przedstawicielami różnych środowisk (dążących do skrajnie różnych celów). W końcu osiągnięto kompromis, który został ujęty w treści tego aktu prawnego. Regulacja ta była na tyle dobra i trwała, że po II wojnie światowej została wszczepiona do ustawy zasadniczej z 1949 roku $^{22}$.

W konstytucji został ujęty także szereg praw i obowiązków dotyczących oświaty i szkolnictwa. Przewidziano powszechny dostęp do szkolnictwa publicznego (art. 142 i 143) i wprowadzono obowiązek szkolny do ukończenia 18 roku życia (art. 145). Szkoła miała nie tylko uczyć, ale i wychowywać - uczyć obywatelskiej postawy oraz wpajać wartości moralne, a także osobiste i zawodowe kompetencje w duchu narodu niemieckiego (art. 148).

Konstytucja była też gwarantem szeregu praw dotyczących życia gospodarczego, które je liberalizowały. Zapewniała wolność gospodarczą (art. 151) i swobodę zawierania umów (art. 152). Była też poręczeniem własności (art. 153). Na jej podstawie zniesione zostały także fideikomisy (art. 155). Jednakże strony nakładała pewne ograniczenia, wprowadzając przepisy o szczególnej ochronie pracy (art. 157), nadaniu praw społecznych pracownikom (art. 162) czy też o ustawowym przeniesieniu własności przedsiębiorstw prywatnych na rzecz ogółu. Takie łączenie elementów wolnościowych i zabezpieczeń społecznych charakterystyczne jest również dla współczesnego ustawodawcy, co daje podstawy do stwierdzenia, że i w tym

${ }^{22}$ Zob. ibidem, s. 268. 
aspekcie konstytucja wprowadzała nowoczesne standardy w swoich unormowaniach.

Zgodnie z tytułem część I konstytucji weimarskiej definiowała nie tylko prawa, ale też obowiązki obywateli Rzeszy. Ogólnie jednak liczba obowiązków wyrażona w konstytucji była nieporównywalnie mniejsza od liczby praw tam zawartych. Do najważniejszych obowiązków zaliczyć należy: służbę państwu i służbę wojskową (art. 133) oraz obowiązek ponoszenia ciężarów publicznych (art. 134).

\section{Praktyka konstytucyjna}

Ocena treści konstytucji weimarskiej z pewnością jest pozytywna. $Z$ punktu widzenia legislatywy był to bardzo dobry technicznie akt spójny i klarowny, dokładnie regulował ustrój Rzeszy, strukturę i kompetencje poszczególnych jej organów, a także kwestie praw i obowiązków obywateli. Rozwiązania prawne, które wprowadzał, były na najwyższym poziomie, często zadziwiały swą nowością. Bez wątpienia współcześnie większość $z$ nich bezproblemowo można by włączyć do aktów konstytucyjnych. Dlaczego zatem w czasie obowiązywania tej demokratycznej konstytucji dokonała się totalitaryzacja państwa niemieckiego? Jak przebiegał ten proces? Jak to się stało, że tak demokratyczne przepisy nie zapobiegły, a może nawet umożliwiły wszystko to, co stało się po 1919 roku?

Niewątpliwie zagadnienie to jawi się jako paradoksalne - najbardziej demokratyczna konstytucja niemiecka (przed II wojną światową) pozwoliła na system rządów totalitarnych ${ }^{23}$. Uzasadniona wydaje się teza, że same regulacje konstytucyjnoprawne nie były wadliwe, a przyczyna jest inna. To praktyka nie odzwierciedliła dobrych założeń - bardzo szybko okazało się, że sytuacja ówczesnych Niemiec nie dorastała do uregulowań zawartych w konstytucji, wobec czego nie dała ona sobie rady w zetknięciu z rzeczywistością. Nie poradziła sobie w fatalnej sytuacji społecznej, politycznej i gospodarczej. „Republika Weimarska była w pierwszych latach

${ }^{23}$ Por. K. Kamińska, A. Gaca, op.cit., s. 622. 
istnienia narażona na ciągłe wstrząsy"24. Dochodziło do ciągłych strajków, prób przewrotów politycznych, a władza była niestabilna. Poza tym mentalność większości społeczeństwa nie przystawała do demokratycznych rozwiązań zawartych w konstytucji. Ówczesna społeczność niemiecka nie była zadowolona $z$ formy państwa, którą jej narzucono po I wojnie światowej. Republika kojarzyła się z klęską Niemiec, traktowano więc taki stan rzeczy jako przejściowy, oczekując na przywrócenie potęgi państwu.

Kolejnym problemem była rola, jaką pełniły partie polityczne. Konstytucja gwarantowała swobodę ich działalności. Tutaj także zawiodła praktyka, ich bowiem celem było reprezentowanie swoich partykularnych interesów, a nie wzięcie odpowiedzialności za losy państwa. Trudno było o współpracę między nimi, a co za tym idzie o polepszenie sytuacji. Brakowało w tym czasie skutecznych inicjatyw, które mogłyby poprawić stan kraju. $Z$ jednej strony i do głosu zaczynały dochodzić także bardziej radykalne partie, $z$ drugiej zaś ugrupowania centrystyczne również okresowo uzyskiwały poparcie. Na boczny tor polityki zostali natomiast zepchnięci liberałowie, których obwiniano za fatalną sytuację $\mathrm{w} \mathrm{kraju}^{25}$. Powszechna była także krytyka traktatu wersalskiego i jego postanowień. W takich okolicznościach doszło do nieudanego puczu Kappa (1920 r.) i puczu monachijskiego (1923 r.). Rozwijał się militaryzm i był on wspierany jako jedna $z$ dróg odbudowy państwa. Na marginesie tego zagadnienia warto przyjrzeć się orzecznictwu sądowemu tego okresu w sprawach politycznych. Christian Krockow określa je ,jako pasmo skandali, jako systematyczne naginanie prawa, a w rezultacie jego burzenie. Podczas, gdy "na lewo" reagowano z przesadną ostrością, prawe oko wydawało się ślepe" ${ }^{26}$. Niezaprzeczalnie taka

${ }^{24}$ B. Bankowicz, M. Bankowicz, A. Dudek, Stownik historii XX wieku, Kraków 1993, s. 416.

${ }^{25}$ Ówczesne nastroje społeczne najlepiej obrazowały wyniki wyborów. Szerzej na ten temat zob. M. Botzenhart, Deutsche Verfassungsgeschichte 1806-1949, Stuttgart 1993, s. 156-161.

${ }^{26}$ C. Krockow, Niemcy. Ostatnie sto lat, tłum. A. Kopacki, Warszawa 1997, s. 130. Dzisiaj określenie NSDAP jako partii prawicowej jest dla niektórych badaczy mocno kontrowersyjne. 
postawa sądów była pewnym wsparciem dla partii faszystowskiej w drodze po władzę.

Wobec swoistego chaosu w państwie nasilała się tęsknota za silną władzą wykonawczą ${ }^{27}$, a nawet za stabilizacją poprzez dyktaturę. To właśnie na fali tego typu odczuć Adolf Hitler dojdzie później do władzy. Tymczasem jednak tworzyła się i utrwalała praktyka osobistych rządów Prezydenta - skupiał on w swoim ręku coraz większą władzę, chętnie korzystał $z$ art. 48 konstytucji, który dawał mu bardzo szerokie uprawnienia ${ }^{28}$. Ważne są tutaj zwłaszcza dwa aspekty. Pierwszy dotyczący podporządkowania krajów związkowych - chociaż Rzesza zostawiała pewne pole swobody w określonych dziedzinach, to jednak landy podlegały jej pełnej kontroli właśnie za sprawą Prezydenta, który miał prawo egzekwowania wykonania obowiązków nałożonych przez ustawodawstwo Rzeszy przy pomocy sił zbrojnych. A to właśnie ono regulowało najważniejsze kwestie - w przypadku konfliktu między prawem Rzeszy a landu prymat miało to pierwsze. Oczywiste staje się więc, że choć konstytucja zakładała federacyjny charakter państwa, to jednocześnie tworzyła instrumenty, które mogły wspierać jego unitaryzację. Jak pokazuje praktyka konstytucyjna, zwłaszcza lat 1933-1945, art. 48 miał głębsze znaczenie. Trudno przypisywać ustawodawcy w 1919 roku chęć wspierania faszyzmu, jednak artykuł ten dawał Hitlerowi idealne narzędzie do narzucenia swej ideologii w całym państwie, niezależnie od postaw krajów związkowych. Drugi aspekt art. 48 dotyczył kwestii praw i wolności, które Prezydent mógł zupełnie lub częściowo zawiesić w przypadku naruszenia czy też

${ }^{27}$ Koncepcja silnej władzy Prezydenta obecna była nie tylko wśród społeczeństwa, ale także wśród polityków czy prawników. Przykładem może być np. projekt „państwa prezydencko-autorytatywnego” Franza von Papena. Zob. D. Willoweit, op.cit, s. 332-333, tłum. autorki.

${ }^{28}$ Treść art. 48 omówiłam, opisując uregulowania konstytucji weimarskiej dotyczące kompetencji Prezydenta. Dla przypomnienia przytaczam poniżej wspomniany fragment: „Na podstawie tego przepisu, w przypadku, w którym kraj związkowy nie spełniał obowiązków nałożonych na niego przez konstytucję lub ustawę Rzeszy, Prezydent miał prawo zmusić kraj ten do wykonania tego przy pomocy sił zbrojnych. Artykuł 48 dawał mu także uprawnienia do podobnej interwencji w sytuacji zagrożenia bezpieczeństwa i porządku publicznego oraz częściowego lub całkowitego zawieszenia niektórych praw i wolności”. 
tylko zagrożenia bezpieczeństwa publicznego Rzeszy. W sprawie szczegółowych regulacji konstytucja odsyłała do ustaw Rzeszy. Można jednak stwierdzić, że sytuacje, w których Prezydent miał prawo do interwencji, nie zostały klarownie dookreślone, co z kolei dawało podstawy do ewentualnych nadużyć. Tak silne zarysowanie władzy Prezydenta w bardzo demokratycznym akcie prawnym, jakim była konstytucja weimarska, może dziwić. Badacze tego zagadnienia sądzą, że wynikało to $z$ mentalności autorów konstytucji. Tworzyli ją bowiem w duchu idei parlamentaryzmu, aczkolwiek ciągle w pamięci mieli silną władzę jednostki (monarchy). Stąd też charakterystyczny jest tu pewien dualizm organów państwowych $z$ jednej strony parlament wybierany przez ogół obywateli, $z$ drugiej prezydent jako niby-cesarz ${ }^{29}$.

Kompromisowy charakter konstytucji widoczny był również w kwestii praw i wolności. Bogaty ich katalog funkcjonował tylko w teorii - brakowało szczegółowych regulacji, które umożliwiłyby jego zaistnienie w rzeczywistości. Wyrażony w luźnym wyliczeniu postulatów i zapisaniu pięknych idei oczekiwał na konkretyzację w ustawach zwykłych ${ }^{30}$. W latach 1919-1933 wiele $z$ nich pozostało „martwą literą prawa”, a od 1933 roku były one radykalnie ograniczane, mimo iż konstytucja formalnie obowiązywała do upadku III Rzeszy. Poza tym administracja państwowa wywodząca się jeszcze z czasów II Rzeszy bojkotowała nowe przepisy. Mimo to wizja wolnego i solidarnego społeczeństwa obywatelskiego była obecna nie tylko w roku 1919, ale trwała aż do zmierzchu republiki ${ }^{31}$.

Poważnym problemem Republiki Weimarskiej były pozostałości prawne, administracyjne i społeczne po poprzednim ustroju. Chociaż został on obalony po niepowodzeniach wojennych, w wyniku wystąpień społecznych, to darzono go pewnym sentymentem. Przejawiało się to $\mathrm{w}$ postaci tęsknoty za władzą jednostki (przez co dochodziło do np. niekorzystnego rozdwojenia $-z$ jednej strony demokratyczne standardy, $z$ drugiej przepisy, które bardzo łatwo mogły być interpretowane w duchu co najmniej autorytaryzmu

\footnotetext{
29 Por. W. Frotscher, B. Pieroth, op.cit., s. 265; C. Krockow, op.cit., s. 128-129.

30 D. Peukert, Republika Weimarska, Warszawa 2005, s. 52.

31 D. Willoweit, op.cit., s. 319.
} 
albo od początku miały taki charakter), ale też jako nieumiejętność lub też niechęć do przestrzegania nowych regulacji i trwanie w poprzednich rozwiązaniach, mimo istnienia nowych regulacji. Postawa taka była reprezentowana zarówno przez ogół społeczeństwa, jak i osoby pełniące funkcje publiczne. W tym kontekście twierdzenie Anschütza, zanegowane przeze mnie wcześniej w stosunku do teorii, jak najbardziej odzwierciedla praktykę: „konstytucja się zmieniła, to państwo pozostało" 32 . Nowoczesne standardy nie mogły funkcjonować w starej rzeczywistości. Mimo że podjęto próbę zmniejszenia znaczenia Prus ${ }^{33}$ - pozbawienia ich możliwości tak silnego oddziaływania na sprawy całej Rzeszy jak w okresie II Rzeszy, nie udało się to. Chociaż formalnie nie miały już takich uprawnień, pozostały najsilniejszym krajem związkowym Republiki ${ }^{34}$.

Problem owych różnic między teorią a praktyką oraz okoliczności, które doprowadziły do tego rozdźwięku, jest niezwykle złożony. Jedno nie ulega wątpliwości - w rezultacie ta najbardziej demokratyczna konstytucja niemiecka (przed II wojną światową) pozwoliła na system rządów totalitarnych. „Zdobycie władzy przez narodowych socjalistów miało charakter legalny, zgodny z obowiązującą konstytucją i przy znacznym poparciu społecznym”35. W 1932 roku NSDAP wygrała wybory zdobywając 13,7 mln głosów ${ }^{36}$, a 30 stycznia 1933 roku prezydent Paul von Hindenburg powołał Hitlera na Kanclerza Rzeszy. Dwa dni wcześniej zostało wydane rozporządzenie „W sprawie ochrony narodu i państwa” (Verordnung „zum Schutz von Volk und Staat"), na podstawie którego ograniczono prawa zasadnicze, a także ponadkonstytucyjnie wyznaczone granice ${ }^{37}$.

32 G. Anschütz, Die Verfassung, cyt. za: W. Frotscher, B. Pieroth, op.cit., s. 257, tłum. autorki.

${ }^{33}$ Przykładem może być wprowadzenie do treści konstytucji art. 61, zgodnie z którym żaden kraj związkowy nie mógł mieć w Radzie Rzeszy więcej niż $2 / 5$ wszystkich głosów.

${ }^{34}$ K. Kamińska, A. Gaca, op.cit., s. 623.

${ }^{35}$ Dzieje państwa i prawa od starożytności do połowy XX $w$., red.: W. Huba, Warszawa 2002, s. 149.

${ }^{36}$ Dla porównania cztery lata wcześniej jej wynik wynosił zaledwie 800 tys. głosów, a zatem jej poparcie wśród społeczeństwa gwałtownie wzrosło, co obrazuje skalę niezadowolenia społecznego.

${ }^{37}$ D. Willoweit, op.cit., s. 459. 
24 marca 1933 r. Sejm Rzeszy, rezygnując ze wszystkich swoich kompetencji na rzecz Rządu ${ }^{38}$, uchwalił tzw. ustawę o pełnomocnictwach (Ermächtigungsgesetz), która dawała możliwość stanowienia przez Rząd Rzeszy prawa niezgodnego $z$ normami zawartymi w konstytucji ${ }^{39}$. Co więcej - jego zatwierdzenie przez Prezydenta albo Sejm Rzeszy nie było konieczne. Wprowadzenie tej ustawy było wystarczające, by przy dalszym formalnym obowiązywaniu konstytucji z 1919 roku, w rzeczywistości przekazać pełnię władzy na rzecz Rządu (który de facto był zdominowany przez Kanclerza, czyli Hitlera, a zatem już w tym momencie możemy mówić o pełni władzy w jego rękach). Mimo to chcąc zachować pozory legalności, wprowadzano kolejne akty prawne ograniczające czy wręcz znoszące normy zawarte w konstytucji. Ustawa o ujednoliceniu (Erstes Gesetz zur Gleichschaltung der Länder) z 31 marca 1933 roku wprowadziła nowe zasady podziału administracyjnego państwa niemające żadnych punktów wspólnych z przepisami konstytucji. Ustawa rządowa z 14 lipca 1933 roku zakazała tworzenia nowych partii politycznych, a status jedynej legalnie działającej partii przyznała NSDAP, tym samym utrwalając monopartyjny system polityczny. Kolejnym krokiem było wydanie 2 sierpnia 1934 roku $^{40}$ ustawy o głowie państwa Rzeszy Niemieckiej, która koncentrowała władzę w rękach Kanclerza, łącząc kompetencje jego i Prezydenta. Następnym etapem odchodzenia od konstytucji weimarskiej było podporządkowanie rządów krajowych Rządowi Rzeszy, a także zniesienie sejmów krajowych na podstawie ustawy o przebudowie Rzeszy (Gesetz über den Neuaufbau des Reiches) z 30 stycznia 1934 roku, co w rzeczywistości prowadziło do przekształcenia Rzeszy w państwo unitarne ${ }^{41}$. Zmiana systemu państwowego poprzez wydanie szeregu aktów prawnych (choć sprzecznych $z$ konstytucją, zarówno pod względem sposobu ich wydania, jak i materii) niewątpliwie

38 A. Czubiński, J. Strzelczyk, op.cit., s. 320.

39 Było to podwójne odejście od norm konstytucyjnoprawnych - w sensie materialnym: możliwość stanowienia prawa niezgodnego $z$ konstytucją, w sensie formalnym: możliwość stanowienia takiego prawa przez organy do tego nieuprawnione przez konstytucję.

40 Jeszcze w dniu śmierci prezydenta Paula von Hindenburga.

41 Już wcześniej, 14 stycznia 1934 roku, zniesiono Radę Rzeszy. 
świadczy o tym, że naziści chcieli zachować fasadowość instytucji ustrojowych Republiki i że utrzymywali oni pozory ich kontynuacji, co miało stanowić dodatkową legitymizację ich władzy wobec społeczeństwa ${ }^{42}$.

\section{Przesłanie konstytucji weimarskiej}

Czy skoro podczas obowiązywania konstytucji z 11 sierpnia 1919 roku do władzy w Niemczech doszli naziści, pod jej osłoną tworząc system totalitarny, zło, którego konsekwencje dla wszystkich są oczywiste, należy uznać, że była to zła konstytucja? Czy taka powinna być jej ocena, ponieważ stała się podstawą prawną totalitaryzmu? Tak negatywne stwierdzenie jest raczej zbyt daleko idące. Bardziej właściwe byłoby określenie jej jako takiej, która wyprzedzała swoje czasy.

Konstytucja weimarska prawdopodobnie sprawdziłaby się w państwie już demokratycznym, w którym panuje ład, dostatek i dobrobyt. Jednak w kraju, w którym sytuacja społeczno-polityczna ciągle była niestabilna, nie dawała ona dostatecznej ochrony, nie była wystarczającym gwarantem bezpieczeństwa państwa, a przede wszystkim bezpieczeństwa w państwie. Można postawić paradoksalną tezę, że to właśnie z powodu swojej „idealności” (wprowadzenia nowoczesnych demokratycznych standardów, wysokiej jakości regulacji prawnych czy w końcu kompromisowego charakteru, który miał łączyć społeczeństwo) nie sprawdziła się, a w konsekwencji umożliwiła dojście do władzy narodowym socjalistom. O ile bowiem wszystkie wymienione przeze mnie cechy zgodnie można uznać za pozytywne, to w przypadku państwa wyniszczonego wojną, pozbawionego stabilizacji, tak jak było w przypadku Republiki Weimarskiej, są zgubne. Kompromis sprawił, że próbowano połączyć różne koncepcje, a to prowadziło do braku konsekwencji w działalności władzy. „Praktyka ustrojowa [...] wykazała jednak niezdolność elit

${ }^{42}$ G. Górski, S. Salmonowicz, Historia ustrojów państwowych, Warszawa 2001 , s. 646. 
politycznych do wykorzystania mechanizmów konstytucyjnych dla stabilizowania sytuacji wewnętrznej” ${ }^{3}$. Zaś „próba zawarcia w jednym akcie prawnym możliwie wielu koncepcji oraz pozostawienia maksymalnie dużej dozy wolności niewątpliwe uzasadnia nazwanie tej konstytucji «jedną z najbardziej prowolnościowych konstytucji świata", [...] nie została ona jednak przyjęta przez wielu obywateli. Nowy twór zrodzony z demokracji, wolności i społecznej sprawiedliwości był piękną fasadą, jednak stare społeczne fundamenty były za słabe, żeby wypełnić ją życiem i ustabilizować"44. Tym samym można stwierdzić, że choć formalnie konstytucja z 1919 roku weszła w życie, w rzeczywistości nigdy tak naprawdę nie była przestrzegana - ani w latach tzw. Republiki Weimarskiej, ani tym bardziej w III Rzeszy. Ponadto demokracja z góry zakłada duże pole wolności. To z kolei implikuje tworzenie się i działalność różnych, w tym także skrajnych ugrupowań. Te zaś w przypadku niezadowolenia społecznego, „grając na emocjach”, mogą wiele uzyskać, bo nie są ograniczane w swojej początkowej fazie działalności.

Niezaprzeczalnie jednak w teorii był to dobry akt prawny. Świadczy o tym choćby fakt, że w obecnej konstytucji niemieckiej (Grundgesetz für die Bundesrepublik Deutschland) znalazła się część przepisów konstytucji weimarskiej - art. 140 ustawy zasadniczej stanowi: „Postanowienia artykułów 136, 137, 138, 139 i 141 niemieckiej konstytucji z 11 sierpnia 1919 r. są elementem tej ustawy zasadniczej" ${ }^{45}$. Tym samym doceniono kompromisowy charakter ${ }^{46}$ regulacji konstytucji weimarskiej dotyczących relacji państwo - religia i dokonano bezpośredniego ich włączenia do nowej ustawy zasadniczej ${ }^{47}$. Ponadto podczas prac nad nią ustawodawca wielokrotnie

${ }^{43}$ Ibidem, s. 644.

${ }^{44}$ H. Potthoff, Weimarer Verfassung: Ein Kompromiß zwischen Experten, w: Deutsche Verfassungsgeschichte 1849-1919-1949, Bonn 1989, s. 75, tłum. autorki.

${ }^{45}$ Grundgesetz. Kommentar, red. Sachs M., München 2009, s. 2431, tłum. autorki.

${ }^{46}$ Grundgesetz-Kommentar, red. I. Münch, P. Kunig, München 2003, s. 1453.

47 Por. Grundgesetz. Kommentar, s. 2431-2485; Grundgesetz-Kommentar, s. 1451-1482. 
pozytywnie oceniał regulacje konstytucji weimarskiej oraz czerpał z nich, modyfikując je stosownie do wymagań czasu ${ }^{48}$.

Konstytucja weimarska niewątpliwie jest ciekawym aktem prawnym, który $z$ racji dobrych rozwiązań prawnych może być źródłem inspiracji przy tworzeniu nowych regulacji lub też punktem odniesienia w stosunku do tych już istniejących. Znacznie ważniejsze jest jednak przesłanie nie tylko samej konstytucji z 1919 roku, ale przede wszystkim doświadczenia jej praktyki konstytucyjnej, które wskazują, że nawet najlepszy akt normatywny nie jest w stanie zapewnić stabilności państwa oraz poszanowania praw jego obywateli, ponieważ to ludzie, a nie samo prawo, kształtują rzeczywistość.

\section{STRESZCZENIE}

Konstytucja Republiki Weimarskiej z 11 sierpnia 1919 roku jako demokratyczna podstawa prawna totalitarnego państwa

Konstytucja Rzeszy Niemieckiej z 11 sierpnia 1919 roku wprowadzała nowoczesne jak na tamte czasy i demokratyczne standardy będące wówczas całkowitym novum. W art. 1 określiła ustrój państwa jako republikę, w której suwerenem jest lud. Zasada ta była podstawą wszelkich innych przepisów tej konstytucji. Zgodnie $z$ nią organy państwa wybierane były w większości przez ogół obywateli - można zatem określić Republikę jako państwo demokracji reprezentatywnej z silnymi elementami plebiscytowymi. Poza tym ten akt konstytucyjny wprowadzał również szeroki katalog praw i wolności. Można postawić tezę, że unormowania konstytucji weimarskiej mogłyby znaleźć się w każdej współczesnej konstytucji. Niestety, praktyka nie odzwierciedliła tych założeń - bardzo szybko okazało się, że sytuacja ówczesnych Niemiec nie dorastała do przepisów konstytucji. W latach 1919-1933 wiele $z$ nich pozostało "martwą literą prawa”, a od 1933 roku były one radykalnie ograniczane, mimo iż konstytucja formalnie obowiązywała do upadku III Rzeszy. W rezultacie prawa te musiały poczekać ad feliciora tempora. Problem owych różnic między teorią a praktyką, a więc okoliczności, które doprowadziły do tego rozdźwięku, są niezwykle złożone, ale ciekawe. Ta najbardziej demokratyczna konstytucja niemiecka (przed II wojną światową) pozwoliła na system rządów totalitarnych, a nowoczesne

48 Ibidem. 
standardy nie funkcjonowały w starej rzeczywistości. Czy zatem konstytucja weimarska była złą konstytucją czy po prostu wyprzedzała swoje czasy? Można skłaniać się ku tej drugiej tezie, skoro niektóre jej zapisy zostały przeniesione do niemieckiej ustawy zasadniczej z 1949 roku. Na ile jednak uregulowania konstytucji weimarskiej i praktyka konstytucyjna może być przesłaniem dla współczesnego ustawodawcy?

Słowa kluczowe: Konstytucja Rzeszy Niemieckiej z 11 sierpnia 1919 r., Rzesza Niemiecka, Republika weimarska, III Rzesza, demokratyczna konstytucja a totalitaryzacja prawa, prawo w Republice Weimarskiej i prawo w III Rzeszy, ustrój Niemiec 1919-1939, przemiany ustrojowe

\section{SUMMARY}

The Constitution of the German Reich from $11^{\text {th }}$ August 1919 as the democratic legal basis of the totalitarian state

The Constitution of the German Reich from $11^{\text {th }}$ August 1919 introduced new democratic standards which was complete novelty. In Article 1 Constitution specified political system of the state as a republic, in which nation were sovereign. This principle was the basis of all other provisions of the Constitution. Legislative and executive body and others organs generally were chosen by a majority of the citizens - so we can could specify Weimar Republic as a state of representative democracy with strong plebiscite elements. Moreover this constitutional act introduced a wide catalog of rights and freedoms too. We can say that Weimar Constitution rules might be found in every contemporary constitution. Unfortunately, the practice did not reflect in these assumptions - very quickly found out that the situation of the then Germany did not raise to the regulations of the Constitution. Between 1919 and 1933 many of them were "the dead letter of the law" and from 1933 they were radically limited although the Constitution formally was in force till the fall Third Reich. As a result these laws have to wait ad feliciora tempora. The problem of the differences between theory and practice and reasons for this is very complicated, but interesting. This most democratic German constitution (before the II world war) allowed the system of totalitarian rule and her modern standards did not function in old reality. So was Weimar Constitution bad constitution or just was ahead her time? We can take this second opinion, because some rules was included to the Basic Law for the Federal Republic of Germany in 1949. Here is one more question - how regulations of the 
Weimar Constitution and constitutional practice can be a message for the present legislator?

Keywords: The Constitution of the German Reich from $11^{\text {th }}$ August 1919, German Reich, Weimar Republic, Third Reich, democratic constitution and make-law-totalitarian, law in Weimar Republic and law in Third Reich, German system 1919-1939, regime changes

\section{BIBLIOGRAFIA}

Anschütz G., Die Verfassung des Deutschen Reichs vom 11. August 1919, Berlin 1926.

Anschütz G., Die Verfassung des Deutschen Reichs vom 11. August 1919, Berlin 1933.

Bankowicz B., Bankowicz M., Dudek A., Stownik historii XX wieku, Kraków 1993.

Botzenhart M., Deutsche Verfassungsgeschichte 1806-1949, Stuttgart 1993.

Czapliński W., Galos A., Korta A., Historia Niemiec, Wrocław 2010.

Czubiński A., Strzelczyk J., Zarys dziejów Niemiec i państw niemieckich powstałych po II wojnie światowej, Poznań 1986.

Dzieje państwa i prawa od starożytności do połowy XX w., red. W. Huba, Warszawa 2002.

Frotscher W., Pieroth B., Verfassungsgeschichte, München 2013.

Górski G., Salmonowicz S., Historia ustrojów państw, Warszawa 2001.

Grundgesetz-Kommentar, red. I. Münch, P. Kunig, München 2003.

Grundgesetz. Kommentar, red. M. Sachs, München 2009.

Kamińska K., Gaca A., Historia powszechna ustrojów państwowych, Toruń 2011.

Krockow C., Niemcy. Ostatnie sto lat, tłum. A. Kopacki, Warszawa 1997.

Lingelbach G., Weimar 1919 - Weg in eine Demokratie, w: 80 Jahre Weimarer Reichsverfassung - Was ist geblieben?, red. E. Eichenhofer, Tübingen 1999.

Peukert D., Republika Weimarska, Warszawa 2005.

Potthoff H., Weimarer Verfassung: Ein Kompromiß zwischen Experten, w: Deutsche Verfassungsgeschichte 1849-1919-1949, Bonn 1989.

Willoweit D., Deutsche Verfassungsgeschichte. Vom Frankenreich bis zur Wiedervereinigung Deutschlands, München 2013. 
